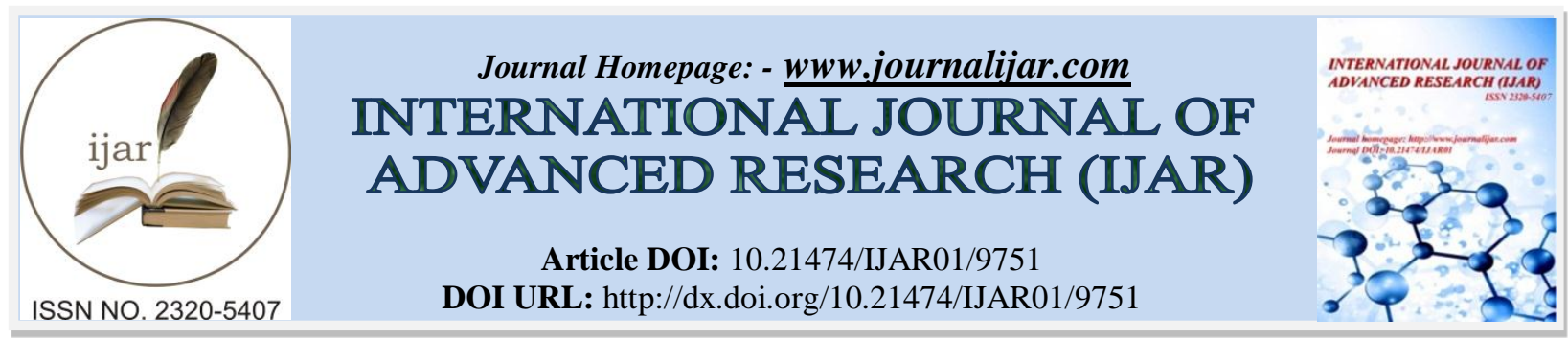

RESEARCH ARTICLE

\title{
CONTAMINATION OF MEAT AND OFFAL (SKIN) BY THE TRACE ELEMENTS METALS DURING THE COOKING GRID OR FOLLOWING PRE-TREATMENT OF STRIPPING TO TIRES.
}

Yaya Coulibaly $^{1}$, Soro Donafologo Baba ${ }^{1}$, Diarra Moussa $^{2}$, Aboua Kouassi Narcisse ${ }^{1}$, Kouadio David Léonce ${ }^{2}$, Ehouman Ano Guy Serge ${ }^{2}$, Meite Ladji ${ }^{1}$, Traore Karim Sory ${ }^{1}$ and Dembele Ardjouma ${ }^{3}$.

1. Laboratory of Environmental Sciences, University of Nangui Abrogoua, 02 BP 801 Abidjan 02, Côte d'Ivoire.

2. University Jean-Lorougnon-Guede, BP 150 Daloa, Côte d'Ivoire.

3. National Laboratory of the Support to the Agricultural Development (LANADA), 04 BP 612 Abidjan 04, Côte d'Ivoire.

\section{Manuscript Info}

Manuscript History

Received: 12 July 2019

Final Accepted: 14 August 2019

Published: September 2019

Key words:-

meat; skin; choukouya; kplo; trace metals

\section{Abstract}

The "choukouya", beef cooked on artisanal metal barbecues powered mainly with rubber woods, is being a high consumption in Côte d'Ivoire, particularly in Abidjan, in the towns of Port-Bouët and Yopougon. It is the same for the "kplo", ox stripped to the fire made of used tires and rubber debris, especially in the communes of Abobo and Port-Bouët. These cooking process generate toxic compounds among which are the trace elements metals (TEM), carcinogenic or mutagenic. The objective of the study is to determine the levels of contamination of meat and offal (skin) by the TEM (cadmium, mercury, lead). Thus, 60 samples of meat and 60 samples of skin were collected, mineralized in acidic medium and assayed by atomic absorption spectrophotometry (AAS). The results indicate that in the samples of meat lead presents the highest average levels, with $0.490 \mathrm{mg} / \mathrm{kg}$ and $0.446 \mathrm{mg} / \mathrm{kg}$ respectively at Port-Bouët and Yopougon. In the skin samples also, lead has the highest average concentrations with respectively 0.605 $\mathrm{mg} / \mathrm{kg}$ and $1.457 \mathrm{mg} / \mathrm{kg}$ at Abobo and Port-Bouët. These values are beyond the European Union standard $(0.1 \mathrm{mg} / \mathrm{kg})$. Mercury and cadmium levels are below their limits which are respectively $0.5 \mathrm{mg} / \mathrm{kg}$ and $0.05 \mathrm{mg} / \mathrm{kg}$ regardless to the matrix and the commune.

Copy Right, IJAR, 2019,. All rights reserved.

\section{Introduction:-}

A significant amount of meat and offal is traded poorly but fairly dynamically in Côte d'Ivoire (Minagri, 2009). Especially, grilled beef, commonly known as "choukouya" is very popular. However, the conditions of its cooking by the craftsmen leave doubts as to the hygienic quality of this food. Indeed, the various fuels used are not advisable. These are rubber woods, wood from evacuation operations often covered with paint, varnish, mothproofs etc. In addition, the metal barrels often painted or having contained various chemicals are used for the construction of the artisanal cooking ovens of this meat.

Pickled beef skin, commonly known as "kplo" is heavily consumed in Côte d'Ivoire. One of the practices increasingly in progress and specifically in Abidjan, is to strip the skins of slaughtered animals (oxen, sheep, goats ...) with fires made from used tires and rubber debris instead of wood, too expensive and because of the high

Corresponding Author:-Yaya Coulibaly.

Address:-Laboratory of Environmental Sciences, University of Nangui Abrogoua, 02 BP 801 Abidjan 1020 02. Côte d'Ivoire. 
calorific value of rubber (PCI) $(40000 \mathrm{~kJ} / \mathrm{kg}$ ) (Chanclou, 2000). Indeed, the intensification of car traffic generates used tires that are available at low cost and sometimes free for craftsmen.

These techniques of meat preparation and tire stripping to obtain "kplo" are likely to generate or transfer toxic compounds in these foods during their preparation. Among these compounds are trace elements metals (TEM), carcinogens or mutagens (ALIAPUR, 2009 ; INERIS, 2002). These pollutants could thus contaminate foods, pollute the environment and ultimately constitute a risk for the health of large consumers.

Already, ivorian data indicate 15,000 to 20,000 new cases of cancer per year of which $20 \%$ are related to food (ALIAM/AILC, 2014). In response to this situation, the State has given priority to food safety through quality control by adopting Maximum Residue Limits (MRLs) or health and hygiene standards. The objective of this study is to determine the levels of contamination of meat and offal (skins) by TEM (cadmium,mercury and lead).

\section{Material and methods \\ Biological material:}

The biological material consists of :

1. ox skin from stripping with tires or rubberwood;

2. beef tenderloin cooked at the grill.

\section{Reagents and solvents}

The nitric acid $\left(\mathrm{HNO}_{3}\right)$ 65\% concentrated used was supplied by Fluka. Hydrogen peroxide $\left(\mathrm{H}_{2} \mathrm{O}_{2}\right)$ to $30 \%$ is produced by Merck. Chloride of Tin to $25 \%$ comes from Merck. The certified standard stallions of cadmium, mercury and lead were provided by Sigma-Aldrich. All the other products that are used are greater than $98 \%$ purity. Water bi-distilled served for the preparation of solutions.

\section{Methods:-}

The study took place in the district of Abidjan, in the Republic of Côte d'Ivoire. Three communes in the district have been accepted namely Abobo, Yopougon, and Port-Bouët. This choice was motivated by the intensity of the stripping and restoration activities in these municipalities. Indeed, they are strong human dominance with a concentration of restaurants and points of sale of grilled meat, especially in Abobo and Yopougon. In addition, the municipality of Port-Bouët hosts the slaughterhouse of Abidjan around which many commercial and gastronomic activities are developed. Sites are identified in different areas; they refer to restaurants, stores of meat cooked to the grill and places of stripping. Figure 1 below shows the study areas.

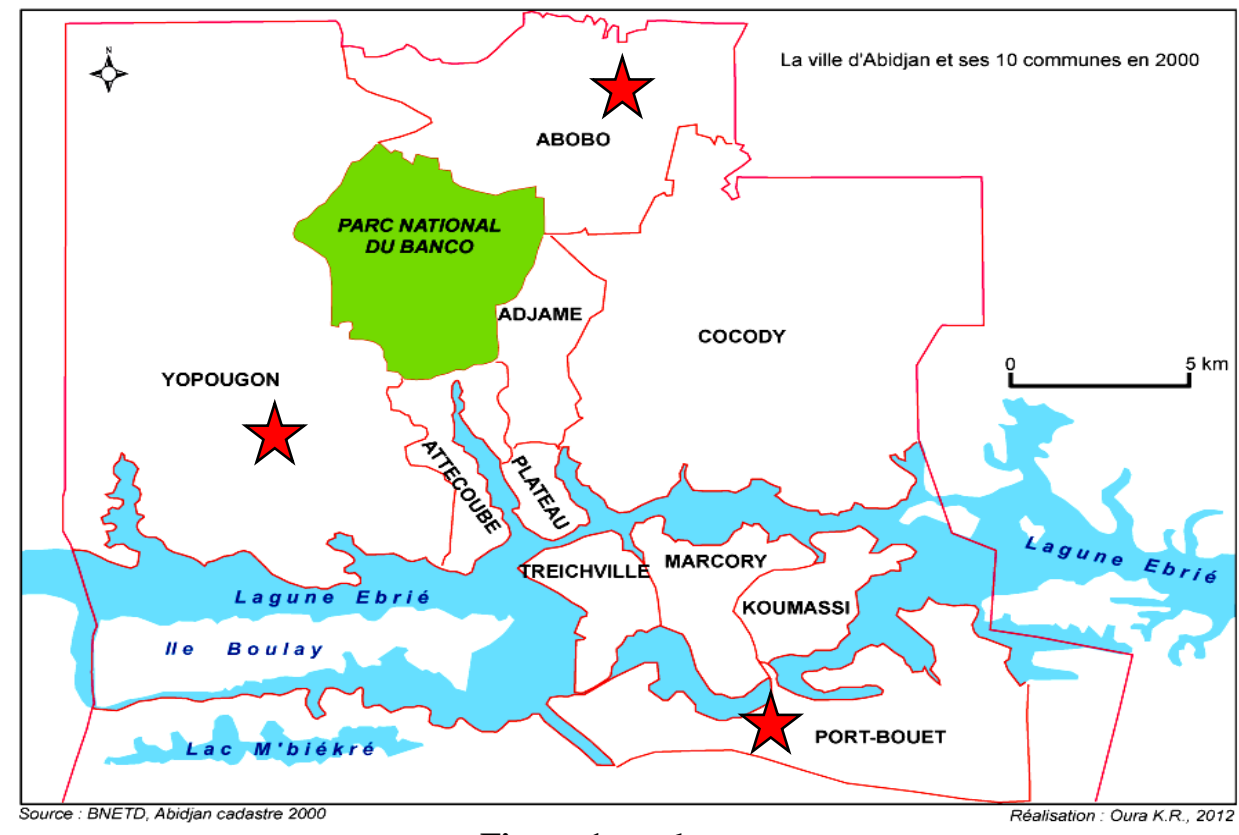

Figure 1:-study areas 


\section{Samples of skins}

Skins sampling area consists of the communes of Abobo and Port-Bouët. Two sites were chosen for their intense activity of stripping in these municipalities. The site located in the commune of Abobo is identified by coordinates GPS $5^{\circ} 27^{\prime} 4$ "N and 358'29" $\mathrm{W}$ and that of the commune of Port-Bouet has coordinates GPS $5^{\circ} 15^{\prime} 45^{\prime \prime} \mathrm{N}$ and $3^{\circ} 58^{\prime} 11^{\prime \prime} \mathrm{W}$. The sampling was random and took in two campaigns. The first took place in March 2017 and devoted itself to the collection of samples of Abobo. As for the second, it took place in August 2017 and it concerned sampling of skin at Port-Bouët. In each municipality, pieces of skin from pre-treatment to tires are bought with the craftsmen of the stripping and handed over to the conservators to be cleaned before cooking. Purchases of the skins are spread over 5 foci (combustion areas) arbitrarily selected on the stripping site. A pre-treatment of the skins to the potash is mainly practised by the conservators. According to these, it helps to soften and facilitate their cooking. Because of the widespread nature of this type of cooking, pieces of skin have undergone the same pre-treatment. Thus, $5 \mathrm{~kg}$ of ox skin have been cleaned, cut and introduced in $10 \mathrm{~L}$ of water ; $20 \mathrm{~g}$ of potash have been added and the whole was brought to cooking for 5 hours. After cooking, the skins were cooled and 30 of almost equal size lots were formed randomly. Each lot represents a sample. All of the samples was then conditioned in food bags to avoid contamination and then transported to the laboratory and stored in the freezer at a temperature of $-4{ }^{\circ} \mathrm{C}$. By commune, 30 samples are made up of 60 samples on the whole of the two communes.

\section{Samples of meat}

The towns of Port-Bouët and Yopougon are the meat sampling area. Six sites of the meat were retained in these communes, due to three per commune and their GPS coordinates are shown in Table 1 below

Table 1:-GPS coordinates of meat cooking sites

\begin{tabular}{|c|c|c|}
\hline Sites & Port-Bouët & Yopougon \\
\hline I & $5^{\circ} 15^{\prime} 34^{\prime \prime} \mathrm{N}$ and $3^{\circ} 58^{\prime} 5^{\prime \prime} \mathrm{W}$ & $5^{\circ} 21^{\prime} 18^{\prime \prime} \mathrm{N}$ and $4^{\circ} 4^{\prime} 45^{\prime \prime} \mathrm{W}$ \\
\hline II & $5^{\circ} 15^{\prime} 35^{\prime \prime} \mathrm{N}$ and $3^{\circ} 58^{\prime} 9^{\prime \prime} \mathrm{W}$ & $5^{\circ} 21^{\prime} 14^{\prime \prime} \mathrm{N}$ and $4^{\circ} 4^{\prime} 27^{\prime \prime} \mathrm{W}$ \\
\hline III & $5^{\circ} 15^{\prime} 33^{\prime \prime} \mathrm{N}$ and $3^{\circ} 58^{\prime} 8^{\prime \prime} \mathrm{W}$ & $5^{\circ} 20^{\prime} 47^{\prime \prime} \mathrm{N}$ and $4^{\circ} 3^{\prime} 54^{\prime \prime} \mathrm{W}$ \\
\hline
\end{tabular}

The sample was random and it held on two campaigns. The first took place in February 2017 and devoted itself to the collection of samples of Yopougon. The second occurred in July 2017 in the commune of Port-Bouet. Beef was bought and handed over to the grilling artisans to be cooked. After baking and cooling, lots of almost identical size are formed and put in food bags. Each lot is a sample. All of the samples were then packaged in plastic freezer bags and stored in a cooler. Finally, they were transported to the laboratory and stored at a temperature of $-4^{\circ} \mathrm{C}$. By commune 30 samples consist; which makes a total of 60 samples for the two communes.

\section{Methods of analysis:-}

The dosage of cadmium and lead were made according to the method AOAC 999.10 (2000) and that of mercury used the method AOAC 971.21 (2000). The principle of these methods consists first of a mineralization of the sample to the acid then a dosage using an atomic absorption spectrophotometer. Samples (meat and skin) removed from the freezer and thawed at room temperature $\left(25^{\circ} \mathrm{C}\right)$, were crushed with the help of a turbo-grinder.

To $0.5 \mathrm{~g}$ taken from the crushed and introduced in bombs of mineralization, were added $7 \mathrm{~mL}$ of nitric acid $\left(\mathrm{HNO}_{3}\right)$, concentrated $65 \%$ and $1 \mathrm{~mL}$ of peroxide $\left(\mathrm{H}_{2} \mathrm{O}_{2}\right) 30 \%$. The mixture was placed in a waterbath for 3 hours. Then, the bombs of mineralization have been removed and cooled under the hood. After cooling, the mineralisats have been recovered in vials of $25 \mathrm{~mL}$ and filled to the mark with water bi-distilled to be analyzed.

The mineralisats obtained were analyzed with an atomic absorption spectrophotometer (AAS) equipped with a graphite oven and a sample changer. Its mark is VARIAN SPECTRAA 110 series. The analysis conditions were depending on searched pollutants.

\section{Dosage of cadmium and lead}

After homogenization of the mineralisats, a volume of $1.5 \mathrm{~mL}$ is taken and put in buckets for the Ferryman of samples of the atomic absorption spectrophotometer. The injected volume in the oven was of $10 \mu \mathrm{L}$. The wavelengths of absorption of $\mathrm{Cd}$ and $\mathrm{Pb}$ were respectively $228.8 \mathrm{~nm}$ and $217.0 \mathrm{~nm}$. The concentrations of the pollutants found in the samples are determined by comparison between the absorbances measured of samples and a range of stallions solutions. 


\section{Determination of mercury}

In the mineralisats, thiolates ions are reduced to elemental mercury by a gear: chloride of Tin to $25 \%$. The mercury atoms are routed in gaseous form in a cell by bubbling of inert gas (nitrogen). The mercury in the cell is measured by spectrophotometry of atomic absorption with formation of cold vapor to the wavelength of $253.7 \mathrm{~nm}$. The concentration of the sample is determined as previously.

\section{Results and discussion:-}

Levels of contamination of hides

Figure 2 shows TEM average levels in skin samples from the two towns (Abobo and Port-Bouët).

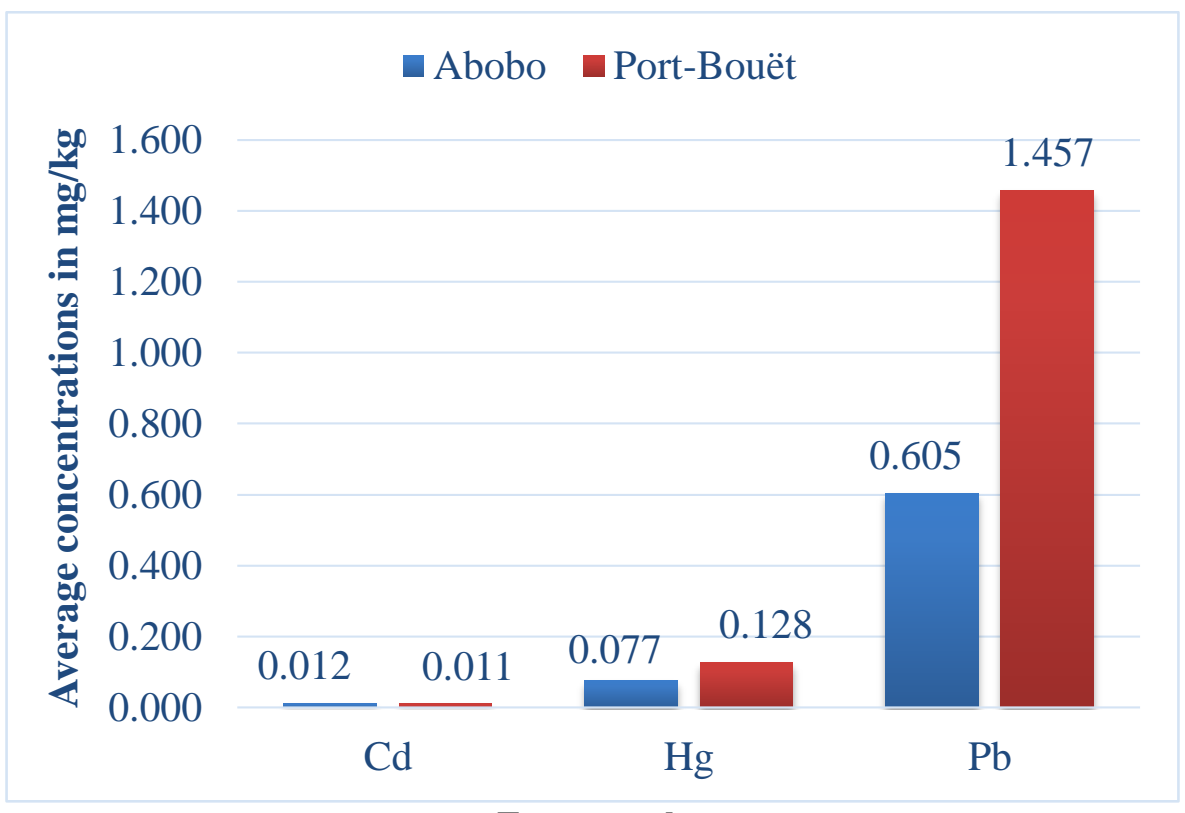

Trace metals

Figure 2:-Trace metals medium levels in samples of skin

At Abobo, skin samples contain the analyzed TEM but at various concentrations. The lead was detected in $70 \%$ of the samples. The highest mean concentration is observed in the case of this metal with a value of $0.605 \mathrm{mg} / \mathrm{kg}$. Cadmium has the lowest concentration : $0.012 \mathrm{mg} / \mathrm{kg}$. The presence of the TEM in skin samples could be explained essentially by the fuels used for pickling. Indeed, although studies have shown that these compounds are accumulated in the kidneys and liver of animals during their life (Miquel, 2001; EFSA, 2009; 2010), no link is established regarding their transfer of these organs to the skin and vice versa. Also, the accumulation of these TEM in the skin does not seem to contribute to a significant part in the resulting content.

The high value of the lead concentration in the skins could be explained by the significant amount of this pollutant in the used fuel (used tires, plastics from the old battery) (INERIS, 2009). By comparing the levels of these pollutants with standards, the average content of lead $(0.605 \mathrm{mg} / \mathrm{kg})$ is largely beyond the standard imposed by the European Union $(0.1 \mathrm{mg} / \mathrm{kg})$ (CE, 2006). On the other hand, the average content of mercury $(0,077 \mathrm{mg} / \mathrm{kg})$ is below the limit set in United States and Canada which is $0.5 \mathrm{mg} / \mathrm{kg}$ (Thibaud, 1971). It is the same for cadmium whose average content $(0.012 \mathrm{mg} / \mathrm{kg})$ is less than its MRLs set by the European Union, which is $0.05 \mathrm{mg} / \mathrm{kg}$ (CE, 2006).

At Port-Bouet, the three TEM sought are present in the samples but at very different levels. The lead was detected in $66.66 \%$ of the samples. Its average content is highest with a value of $1.457 \mathrm{mg} / \mathrm{kg}$. As for mercury and cadmium, the average levels measured in samples were respectively $0.128 \mathrm{mg} / \mathrm{kg}$ and $0.011 \mathrm{mg} / \mathrm{kg}$. These results could be explained as previously by the process of stripping employed by craftsmen using rubber materials or plastic as fuel. The comparison of the average contents of different TEM in the samples with standards, indicates for lead value $(1.457 \mathrm{mg} / \mathrm{kg})$ very superior to the standard $(0.1 \mathrm{mg} / \mathrm{kg})(\mathrm{CE}, 2006)$. However, levels of mercury $(0.128 \mathrm{mg} / \mathrm{kg})$ and cadmium $(0.011 \mathrm{mg} / \mathrm{kg}$ ) are still below their limits which are respectively $0.5 \mathrm{mg} / \mathrm{kg}$ (Thibaud, 1971) and 0.05 $\mathrm{mg} / \mathrm{kg}$ (CE, 2006). 
A comparison of the results shows that skin samples from the commune of Port-Bouët display the highest concentrations of lead and mercury. These results could be explained by the fact that during the stripping, worn tires, most of the wood of abandonment carrying the painting, are relatively more used as fuel at Port-Bouët, according to a survey in the field. Also, in the slaughter of this commune, beef skins lying around on the muddy floor right next to the lagoon. Also, some craftsmen after stripping, dive skins in the lagoon for a first softening, to facilitate cooking. However, studies have shown the contamination of the lagoon by the TEM such as for example the lead and mercury (Soro et al., 2009 ; Adingra et Kouassi, 2011; Traoré et al., 2014 ).

With respect to the levels of cadmium, a slight increase is observed in samples of the commune of Abobo with an average grade of $0.012 \mathrm{mg} / \mathrm{kg}$ compared to those of Port-Bouët $(0.011 \mathrm{mg} / \mathrm{kg})$.

\section{Levels of contamination of the meat}

Figure 3 shows the medium levels in samples of meat from the two towns (Port-Bouët and Yopougon).

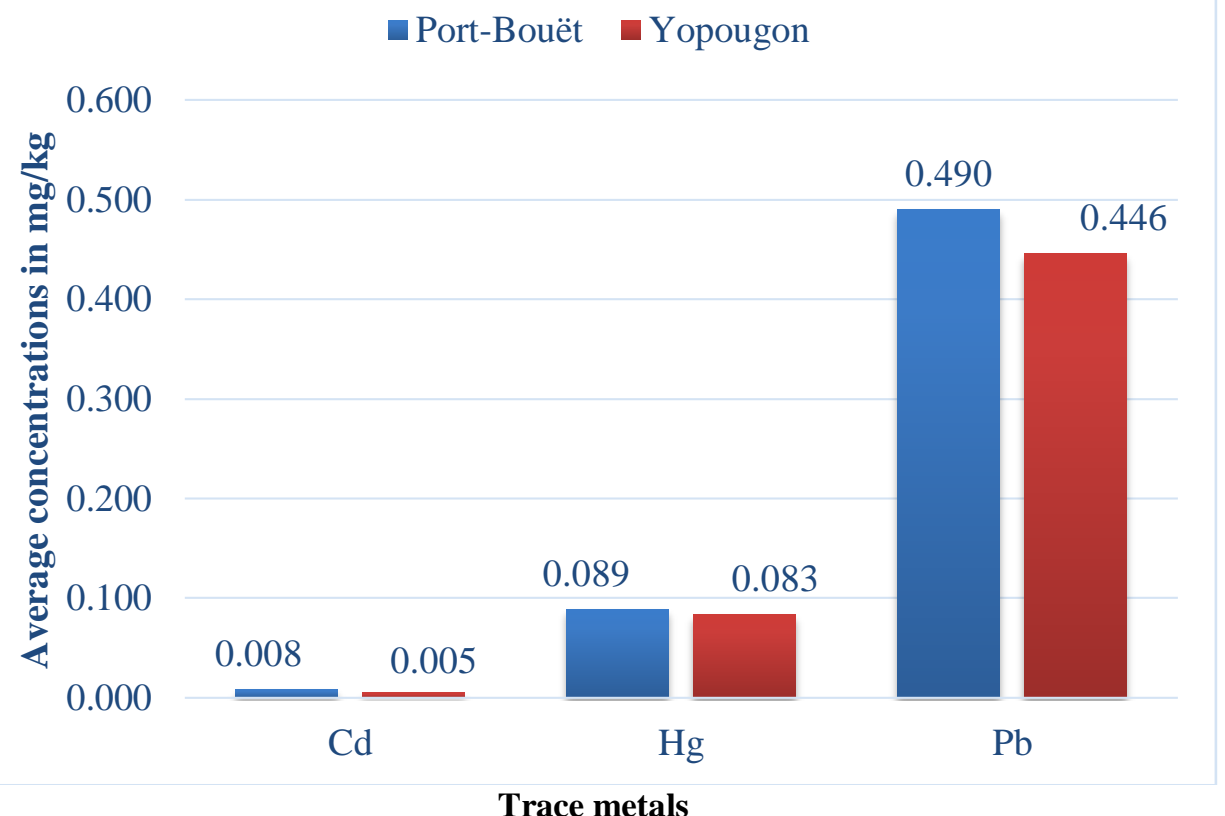

Trace metals

Figure 3:-Trace metals medium levels in meat samples

It is clear that in Port-Bouet, meat samples contain the different analyzed TEM but at various concentrations. The lead has the highest average grade with $0.490 \mathrm{mg} / \mathrm{kg}$, obtained from $90 \%$ of samples in which this metal has been detected. This value is largely beyond the standard imposed by the European Union $(0.1 \mathrm{mg} / \mathrm{kg})$ (CE, 2006). However, levels of mercury $(0.089 \mathrm{mg} / \mathrm{kg})$ and cadmium $(0.008 \mathrm{mg} / \mathrm{kg})$ are still below their limits which are respectively $0.5 \mathrm{mg} / \mathrm{kg}$ (Thibaud, 1971) and $0.05 \mathrm{mg} / \mathrm{kg}$ (CE, 2006). In the area of Yopougon, TEM have been found at various concentrations. The lead was detected in $86.66 \%$ of the samples. As previously, it presents the highest average content which is $0.446 \mathrm{mg} / \mathrm{kg}$ widely beyond the MRL $(0.1 \mathrm{mg} / \mathrm{kg})$. Similarly, the mercury $(0.083$ $\mathrm{mg} / \mathrm{kg})$ and cadmium $(0.005 \mathrm{mg} / \mathrm{kg})$ contents remain below their limits.

The accumulation of TEM in some organs of animals during their life has been proven. This is for example the kidneys and the liver (Miquel, 2001; EFSA, 2009; 2010). Their accumulation in meat does not seem to contribute to a significant part in the resulting content. The presence of the TEM in meat samples could be explained essentially by the materials used in the construction of the metal baking ovens. The high content of lead may have several origins. It could intervene in alloys used in the manufacture of barrels, racks or drums various incoming in the manufacture of kilns. Also, some barrels carry paint that may contain lead; others previously contained different chemicals. Moreover, to complete the cooking, the meat is often in the packaging of cement paper, then posed on the grid. This practice is likely to contamination. 
However, circulation in the muscles were noted regarding the lead (Miquel, 2001) ; what could contribute in part to its relatively high content. In addition, it is clear that samples of meat from the commune of Port-Bouët have highest average levels of lead and mercury. This fact could be explained by additional contamination due to conditions of butchering of animals. Indeed, to clean up the carcasses and offal on the muddy ground of the slaughterhouse in this commune, butchers sometimes use the water of the lagoon, whose pollution in TEM is proven (Soro et al., 2009 ; Adingra et Kouassi, 2011 ; Traoré et al., 2014).

\section{Conclusion:-}

In the samples of skin (kplo) and grilled meat (choukouya), it is clear that lead, mercury and cadmium are present at various concentrations. In the case of the skin, the lead has the highest medium levels with $0.605 \mathrm{mg} / \mathrm{kg}$ and 1.457 $\mathrm{mg} / \mathrm{kg}$ respectively at Abobo and Port-Bouet. Similarly, with respect to meat, lead has the highest medium levels which are $0.490 \mathrm{mg} / \mathrm{kg}$ and $0.446 \mathrm{mg} / \mathrm{kg}$ respectively at Port-Bouët and Yopougon. These values are above the MRL. Mercury and cadmium levels are below their limits regardless of the matrix or the municipality.

\section{Acknowledgments:-}

Thanks are addressed to the craftsmen of the stripping, the cooking grid and the conservators who facilitated the sampling of the skins and meat. They are also expressed in the place of the authorities of the National Laboratory of Support to the Agricultural Development (LANADA) and the University Nangui Abrogoua who have provided material assistance.

\section{References:-}

1. Adingra A. A. et Kouassi M. A. (2011), Pollution en lagune Ebrié et ses impacts sur l'environnement et les populations riveraines, F. Tech. \& Doc. Vulg., pp. 48-53.

2. ALIAM/AILC (2014), Alliance des ligues francophones africaines et méditerranéennes. Association Ivoirienne de Lutte Contre le Cancer. Interview intitulé «manger de la viande braisée est un risque de cancer» 6p.

3. ALIAPUR (2009), Extrait du document de référence ALIAPUR R\&D 2009 sur l'utilisation des pneus usagés comme combustible alternatif : valeurs de référence et protocoles de caractérisation. Aliapur $-\mathrm{R} \& \mathrm{D}-\mathrm{juillet}$ $200915 p$.

4. AOAC 971.21 (2000), Official Method 971.21, Mercury in Foods, Flameless Atomic Absorption Spectrophotometric Method (17th ed.) AOAC : Washington, DC.

5. AOAC 999.10 (2000), Official Method 999.10. Official methods for chemical elements in food of animal origin. Lead, cadmium, zinc, copper and iron in foods. J. AOAC International, 83, 1189p.

6. CE (2006), Règlement (CE) no 1881/2006 de la Commission du 19 décembre 2006 portant fixation de teneurs maximales pour certains contaminants dans les denrées alimentaires, Journal officiel de l'Union européenne, L 364, 24p.

7. Chanclou G. ( 2000), Rupture de chaînes polymères par oxydation contrôlée: Application au recyclage de déchets élastomères. Thèse de doctorat, Université du Maine, Le Mans 208p.

8. EFSA (2009), Scientific opinion on cadmium in food, The Efsa Journal, 980, pp. 1-139.

9. EFSA (2010), Scientific opinion on lead in food, The Efsa Journal, 8(4), pp. 1-147.

10. INERIS (2002, Métaux -mercure. Rapport final. DRC - 02-39266- AIRE /étude 10- 782 fmr., 87p.

11. INERIS (2009), Caractérisation des émissions de polluants engendrés par l'incendie de cinq produits types, Rapport d'Etude DRC-09-93632-01522A 48p.

12. Minagri (2009), Ministère de l'Agriculture, État des ressources phylogénétiques pour l'alimentation et l'agriculture: second rapport national $65 \mathrm{p}$.

13. Miquel G. (2001), Les effets des métaux lourds sur l'environnement et la santé, Rapport Office Parlementaire d'évaluation des choix scientifiques et technologiques (Dir.), Rapport Sénat n²61, 360p.

14. Soro G., Metongo S. B., Soro N., Ahoussi K. E. , Kouamé K. F. , Zade .P G. S. et Soro T. ( 2009), Métaux lourds $(\mathrm{Cu}, \mathrm{Cr}, \mathrm{Mn}$ et $\mathrm{Zn})$ dans les sédiments de surface d'une lagune tropicale africaine : cas de la lagune Ebrié (Côte d'Ivoire), Int. J. Biol.Chem. Sci., 3(6), pp. 1408-1427.

15. Thibaud Y. (1971), Teneur en mercure dans quelques poissons de consommation courante, Sciences et Pêche, Bull. Znst. Pêches maritimes, no 209, décembre, 10p.

16. Traoré A., Soro G., Ahoussi K. E., Bamba B. S., Soro N. et Biémi J. (2014), Niveau de contamination en métaux lourds des sédiments d'une lagune tropicale : la lagune Aghien (Sud-Est de la Côte d'Ivoire), Afrique SCIENCE, 10(3), pp. 73-88. 